\title{
Pembelajaran Luas Permukaan Bangun Ruang Sisi Datar Menggunakan Pendekatan Pendidikan Matematika Realistik Indonesia
}

\author{
Siti Maisyarah ${ }^{1}$, Rully Charitas Indra Prahmana ${ }^{2 *}$ \\ ${ }^{1,2}$ Universitas Ahmad Dahlan, J1. Pramuka No. 42, Pandeyan, Umbulharjo, Yogyakarta, Indonesia \\ *rully.indra@mpmat.uad.ac.id
}

\begin{abstract}
Abstrak
Salah satu materi geometri yang mempunyai tingkat kesulitan dan keabstrakan yang tinggi adalah materi dimensi tiga (bangun ruang), khususnya luas permukaan bangun ruang sisi datar. Siswa mengalami kesulitan dalam membayangkan obyek dan mengkonstruksi pengetahuan yang dimiliki sebelumnya. Salah satu pendekatan yang menggunakan pengetahuan sebelumnya sebagai starting point pembelajaran adalah pendekatan Pendidikan Matematika Realistik Indonesia (PMRI). Penelitian ini merupakan penelitian deskriptif kualitatif yang bertujuan untuk mendeskripsikan pembelajaran luas permukaan bangun ruang sisi datar menggunakan pendekatan PMRI pada siswa kelas VIII di SMP Negeri 1 Banguntapan. Subjek dalam penelitian ini adalah seluruh siswa kelas VIIIC SMP Negeri 1 Banguntapan Yogyakarta. Teknik pengumpulan data menggunakan rekaman video, observasi dan wawancara. Rekaman video dilakukan untuk mengamati kegiatan siswa selama proses pembelajaran dan membandingkannya dengan lembar observasi dan lembar wawancara. Sedangkan, instrument tes digunakan sebagai data pendukung untuk melihat hasil belajar siswa setelah pembelajaran luas permukaan bangun ruang sisi datar secara keseluruhan. Hasil penelitian menunjukkan bahwa selama proses pembelajaran yang berlangsung selama dua pertemuan, siswa dapat mengikuti dengan baik seluruh tahapan pembelajaran dengan memenuhi lima karakteristik PMRI dan mendapatkan hasil yang baik.

Kata kunci: bangun ruang sisi datar, deskriptif kualitatif, Pendidikan Matematika Realistik Indonesia
\end{abstract}

\begin{abstract}
One of the geometry subjects that has a high level of difficulty and abstractness is the 3D-shape subject (solid geometry), especially the surface area of a polyhedron. Students have difficulty in imagining objects and constructing previously owned knowledge. One approach that uses prior knowledge as a starting point for learning is the Indonesian Realistic Mathematics Education (IRME) approach. This research is a qualitative descriptive study that aims to describe the learning of surface area of polyhedron using the IRME approach to eighth-grade students in SMP Negeri 1 Banguntapan. The subjects of this study were all eighth-grade students of SMP Negeri 1 Banguntapan Yogyakarta. Data collection techniques used were video recording, observation, and interviews. Video recording is conducted to observe student activities during the learning process and compare them with observation and interview sheets. Meanwhile, the test instrument is used as supporting data to see student learning outcomes after learning the surface area of the polyhedron as the whole topic. The results showed that during the learning process, which lasted for two meetings, students could follow well all stages of learning by fulfilled the five characteristics of IRME and getting good results.
\end{abstract}

Keywords: Indonesian Realistic Mathematics Education, polyhedron, qualitative descriptive 


\section{Pendahuluan}

Materi geometri menjadi salah satu materi yang masih dianggap sulit oleh siswa, jika dilihat dari cara siswa dalam memecahkan soal-soal geometri yang didasari dari gaya kognitifnya (Winarso \& Dewi, 2017; Novita, Prahmana, Fajri, \& Putra, 2018; Angraini \& Prahmana, 2019). Sejalan dengan itu, Nurhikmayati (2017) menyatakan bahwa salah satu materi yang mempunyai tingkat kesulitan dan keabstrakan yang tinggi adalah materi dimensi tiga (bangun ruang). Di sisi lain, pengajaran geometri merupakan kunci untuk memahami segala bentuk yang ada di lingkungan sekitar kita (Asis \& Arsyad, 2015; Fiantika, Budayasa, \& Lukito, 2017; Umam \& Supiat, 2019). Sehingga, materi geometri dapat dikatakan merupakan salah satu materi yang masih dianggap sulit oleh siswa, walaupun hal ini penting untuk dipelajari, khususnya bangun ruang sisi datar.

Romadiastri (2013) menunjukkan dalam penelitiannya bahwa mahasiswa merasa kesulitan dalam memvisualisasikan bidang datar ke dalam bentuk dimensi tiga pada materi geometri benda putar. Sejumlah penelitian menjelaskan bahwa permasalahan seperti ini dapat diselesaikan dengan pembelajaran yang bersifat mengkonstruksi kemampuan siswa, sehingga siswa dapat memvisualisasikan dan menentukan model yang paling tepat untuk menyelesaikan permasalahan yang diberikan (Prabowo \& Ristiani, 2011; Ahamad, Li, Shahrill, \& Prahmana, 2018; Saputra \& Andriyani, 2019). Oleh karena itu, pembelajaran yang menggunakan kontribusi siswa dalam mengkonstruksi jawaban atas permasalahan geometri yang diberikan mampu membantu siswa dalam menyelesaikan permasalahan tersebut.

Salah satu alternatif pendekatan pembelajaran yang menggunakan kontribusi siswa sebagai wahana dalam kegiatan belajar-mengajar adalah pendekatan Pendidikan Matematika Realistik Indonesia (PMRI) (Wijaya, 2012; Sembiring, Hoogland, \& Dolk, 2010; Hadi, 2017). Pendekatan PMRI adalah pendekatan pembelajaran yang melibatkan siswa untuk lebih aktif dalam menemukan konsep atas suatu materi tertentu dengan mengkonstruksi pemahaman dan kontribusi mereka selama proses pembelajaran (Gravemeijer, 1994; Putri, 2015). Selanjutnya, suatu pembelajaran yang berorientasi kepada prinsip dan karakteristik PMRI mampu membuat siswa mempunyai kesempatan untuk menemukan kembali konsep-konsep matematika atau pengetahuan matematika formal (Diba, Zulkardi, \& Saleh, 2009; Saefudin, 2012; Meryansumayeka \& Suganda, 2018). Tahapan pembelajaran matematika saat ini, sebaiknya diawali dengan masalah kontekstual menuju sesuatu yang abstrak, sehingga pembelajaran matematika menjadi lebih bermakna (Misdalina, Zulkardi, \& Purwoko, 2013; Jannah \& Prahmana, 2019). Oleh sebab itu, pendekatan PMRI mampu memberikan kesempatan kepada siswa untuk berkontribusi atas pengetahuan mereka dalam 
mengkonstruksi pemahaman mereka terhadap materi yang diajarkan melalui permasalahanpermasalahan kontekstual yang diberikan selama kegiatan belajar-mengajar yang bermakna.

Berdasarkan uraian di atas, peneliti tertarik untuk mengimplementasikan pendekatan PMRI pada pembelajaran materi luas permukaan bangun ruang sisi datar. Implementasi ini bertujuan untuk melihat dan mendeskripsikan proses pembelajaran menggunakan pendekatan PMRI terhadap materi luas permukaan bangun ruang sisi datar. Sehingga, hasil ini mampu memberikan gambaran tentang kondisi kegiatan belajar-mengajar luas permukaan bangun ruang sisi datar menggunakan pendekatan PMRI.

\section{Metode}

Penelitian ini merupakan penelitian deskriptif kualitatif yang mendeskripsikan proses kegiatan belajar-mengajar yang dibagi kepada tahapan persiapan, implementasi, dan analisis data (Prahmana, 2017). Kegiatan penelitian ini dilaksanakan di kelas C SMP Negeri 1 Banguntapan, pada Semester Genap, Tahun Ajaran 2018/2019, dengan jumlah peserta didik sebanyak 28 orang. Penelitian dilakukan selama 2 kali pertemuan menggunakan pendekatan Pendidikan Matematika Realistik Indonesia (PMRI) dan 1 pertemuan untuk kegiatan evaluasi pembelajaran untuk melihat hasil implementasi pembelajaran PMRI. Pada pertemuan pertama, peneliti mengimplementasikan PMRI dalam pembelajaran luas permukaan bangun datar dari Kubus dan Balok menggunakan permasalahan yang bersifat kontekstual dalam bentuk Lembar Aktifitas Siswa (LAS) 1. Selanjutnya, pada pertemuan kedua, implementasi PMRI dikhususkan pada pembelajaran luas permukaan bangun datar dari Prisma dan Limas menggunakan permasalahan yang bersifat kontekstual dalam bentuk LAS 2. Terakhir, peneliti memberikan tes evaluasi akhir pembelajaran untuk melihat ketercapaian pemahaman siswa terhadap materi yang diajarkan.

Teknik pengumpulan data yang digunakan dalam penelitian ini adalah observasi, dokumentasi, dan wawancara. Selanjutnya, seluruh data yang telah dikumpulkan, dianalisis secara deskriptif, yang meliputi mereduksi, menampilkan, dan menyimpulkan data yang telah dikumpulkan. Indikator keberhasilan dalam penelitian ini adalah mampu mendeskripsikan proses pembelajaran menggunakan pendekatan PMRI terhadap materi luas permukaan bangun ruang sisi datar, berdasarkan karakteristik dan prinsip-prinsip PMRI. Selain itu, hasil evaluasi pembelajaran yang dilakukan pada pertemuan ketiga dapat dijadikan salah satu indikator keberhasilan implementasi PMRI terhadap pemahaman siswa. 


\section{Hasil Penelitian dan Pembahasan}

Kegiatan pembelajaran dilakukan selama 3 pertemuan. Pada tiap pertemuan, kegiatan belajar-mengajar menggunakan pendekatan PMRI, dengan diberikan Lembar Aktivitas Siswa (LAS) yang terdiri atas 3 aktivitas yang dikerjakan secara berkelompok. Sehingga, siswa dapat berdiskusi dan saling berkontribusi satu sama lain selama proses penyelesaian masalah yang diberikan pada LAS. Selama kegiatan belajar-mengajar, terdapat seorang observer yang mengobservasi proses pembelajaran, untuk mengklarifikasi karakteristik dan prinsip PMRI telah diimplementasikan di kelas. Seluruh proses pembelajaran dideskripsikan untuk memberikan gambaran proses pembelajaran luas permukaan bangun ruang sisi datar menggunakan pendekatan PMRI.

\section{Pertemuan Pertama}

Pertemuan pertama terdiri dari tiga aktivitas, yaitu menemukan rumus dari luas permukaan dari kubus dan balok, menghitung luas permukaan ruang kelas yang dicat, dan menghitung biaya yang diperlukan untuk membungkus kado. Setiap aktivitas memiliki tujuan yang berbeda. Selanjutnya, siswa mengingat kembali konsep luas persegi dan persegi panjang, sebagai dasar memahami konsep luas permukaan bangun ruang sisi datar pada pertemuan pertama. Hal ini, sesuai dengan salah satu karakteristik dari PMRI yaitu dari keterkaitan antar materi (intertwinning) (Gravemeijer, 1994; Wijaya, 2012; Hadi, 2017). Dalam hal ini, pembelajaran luas permukaan bangun sisi datar pada kelas VII memiliki keterkaitan materi dengan pembelajaran luas permukaan bangun ruang sisi datar pada kelas VIII, seperti tampak pada Dialog 1.

\section{Dialog 1}

Guru : Sebelumnya pada kelas VII, apakah kalian sudah pernah mempelajari tentang luas permukaan persegi, tidak?

Siswa : Sudah

Guru : yang kalian ketahui apa?

Siswa : rumusnya adalah s $x \mathrm{~s}$

Guru : apakah persegi seperti ini?

Siswa : Iya

Guru : Jika ini bangun apa?

Siswa : persegi panjang

Guru : antara persegi dengan pesegi panjang bedanya apa?

Siswa : sisi-sisinya. Jika persegi sisi-sinya sama panjang sedangkan persegi panjang 2 sisinya sama panjang sejajar.

Guru : lalu luas permukaan persegi itu apa?

Siswa : s $x$ s

Guru : s x s jika dimisalkan sisi-sisinya adalah $s$ 
Siswa : iya

Guru : untuk luas persegi panjang bagaimana?

Siswa : panjang kali lebar

Guru : panjang kali lebar jika 2 sisinya panjang dan 2 sisi yang lainnya adalah lebar. kenapa mba mengingatkan kembali materi sebelumnya dikarenakan konsep ini akan membantu kalian dalam mempelajari materi hari ini.

Guru memberikan kesempatan pada siswa untuk membayangkan tahapan-tahapan yang harus dilakukan untuk menyelesaikan permasalahan yang diberikan pada setiap LAS. Selanjutnya, Guru membagi seluruh siswa yang berjumlah 28 siswa menjadi 7 kelompok dengan setiap kelompok terdiri dari 4 siswa dan memberikan LAS kepada setiap kelompok untuk diselesaikan. Guru meminta siswa memahami permasalahan yang ada pada LAS tersebut, seperti tampak pada Gambar 1.

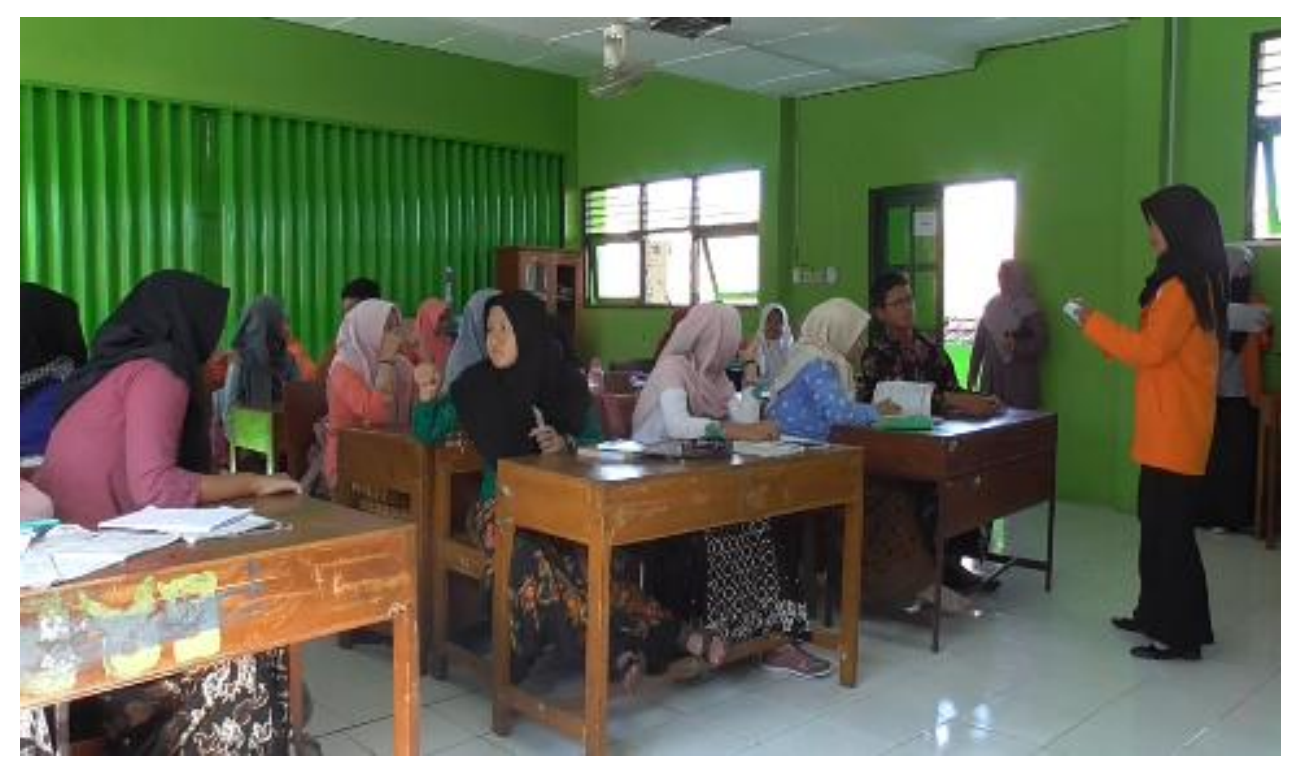

Gambar 1. Guru membagikan dan menginstruksikan pengerjaan LAS

Pada saat membagikan LAS, ada salah satu siswa yang bertanya kepada guru, seperti tampak pada Dialog 2.

\section{Dialog 2}

Siswa : ini langsung dikerjain?

Guru : iya

Siswa : tanpa diberitahu materinya?

Guru : iya sebab ini ada kaitannya dengan Pendekatan Matematika Realistik Indonesia

Siswa : baik mba 
Berdasarkan Dialog 2, siswa tampak bingung dengan diberikannya soal tanpa diberitahu terlebih dahulu materi yang akan dipelajari. Sebab dalam pendekatan PMRI tujuan pembelajaran diberikan diakhir pembelajaran melalui permasalahan-permasalahan dari LAS yang dikerjakan oleh siswa (Prahmana, Zulkardi, \& Hartono, 2012). Berangkat dari permasalahan-permasalahan kontekstual tersebut, siswa diajak untuk memahami konsep luas pemukaan. Berikut ini merupakan deskripsi dari tiga aktivitas pada pertemuan pertama.

1. Menemukan rumus luas permukaan kubus dan balok dengan membentangkan permukaan kotak makanan

Tujuan dari aktivitas ini adalah siswa dapat memahami konsep dari rumus luas permukaan bangun ruang yang dilakukan dengan cara membentangkan permukaan kotak makanan dari Gambar 2. Melalui aktivitas pertama ini, siswa menemukan cara untuk mendapatkan konsep yang menghasilkan rumus seperti pada buku-buku pelajaran matematika yang pada dasarnya sama.

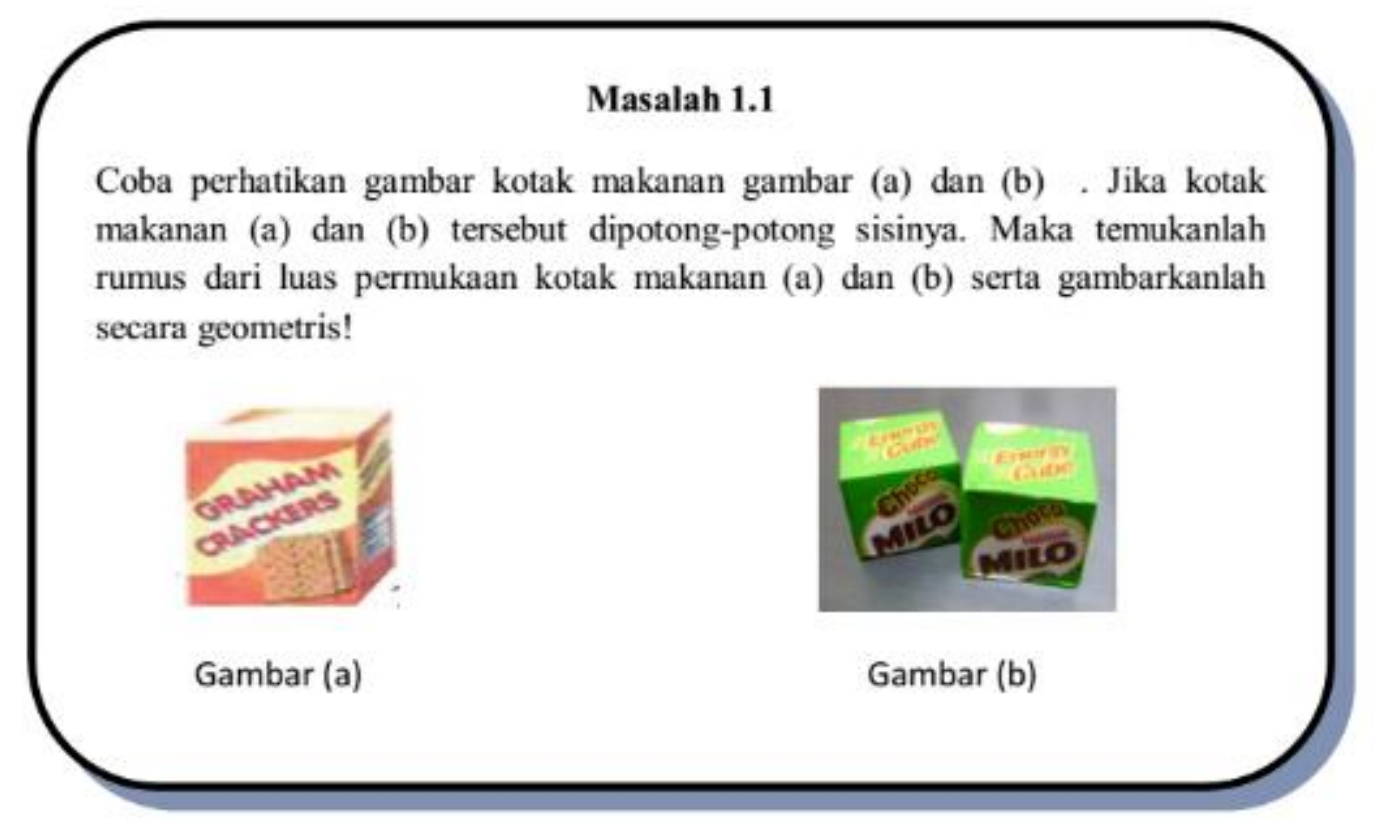

Gambar 2. Masalah 1.1 pada LAS 1

Pada LAS 1 (Gambar 2), siswa diminta untuk menemukan rumus dengan cara membentangkan sisi dari kotak makanan gambar (a) dan gambar (b). Mereka diberi petunjuk dari awal pembelajaran dengan menggunakan konsep luas persegi dan persegi panjang. Sehingga, siswa dapat menemukan rumus dari kotak makanan tersebut. Penggunaan model ini merupakan karakteristik lain dari PMRI. Sebelum siswa melanjutkan pekerjaannya, guru terlebih dahulu memberi petunjuk lain yaitu jika kotak makanan tersebut dibentangkan bagaimanakah kondisi kotak tersebut? Seperti yang terlihat pada Gambar 3. 


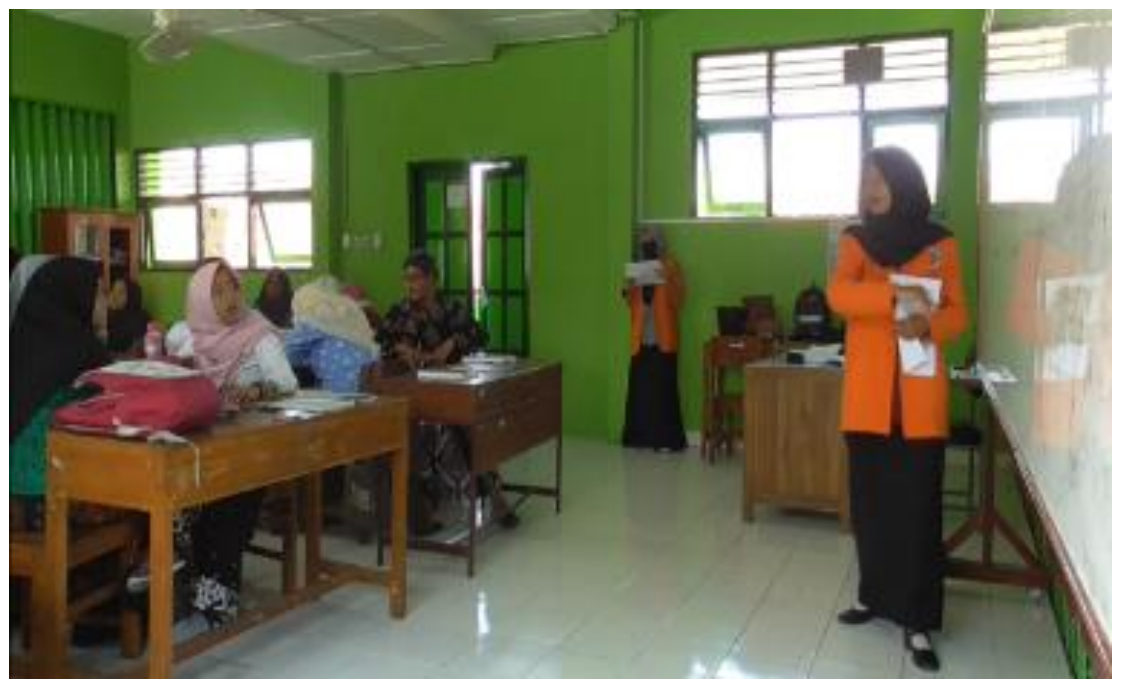

Gambar 3. Guru Memberikan Arahan untuk Menyelesaikan Masalah 1.1

Namun, guru kurang teliti dalam memberikan arahan yang disampaikan seperti yang terlihat pada Dialog 3.

\section{Dialog 3}

Siswa : Untuk gambar jaring-jaringnya harusnya agak memanjang kebawah tidak ya bu?

Guru : Bagaimana?

Siswa : Supaya pas saat dipasang kembali ujung-ujungnya juga harus pas

Guru : Betul sekali (Guru memperbaiki arahannya)

Siswa : Iya bu seperti itu

Guru : Terimakasih ya..

Berdasarkan Dialog 3, siswa memberikan kontribusi melalui pemikiran-pemikirannya, seperti tampak pada Gambar 4. Hal tersebut merupakan salah satu karakteristik dari PMRI, yaitu menggungkan kontribusi siswa dalam menyelesaikan permasalahan yang diberikan pada kegiatan belajar-mengajar (Gravemeijer, 1994; Wijaya, 2012; Hadi, 2017). 


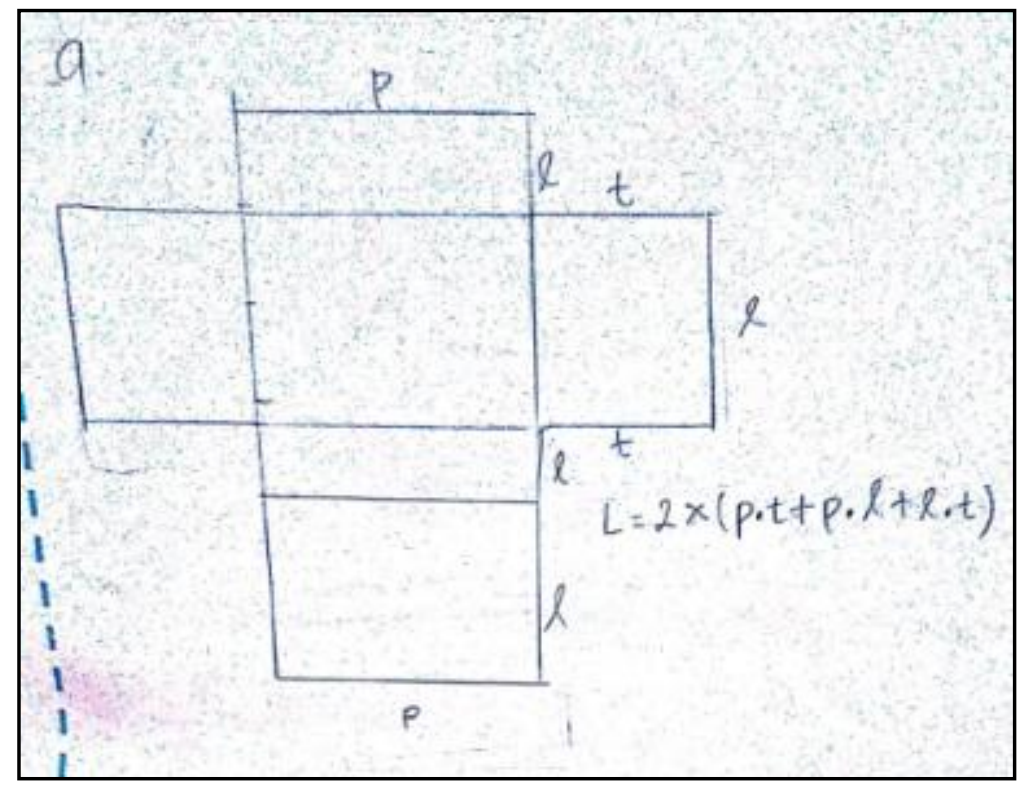

Gambar 4. Jawaban kelompok 1 untuk soal Masalah 1.1

Gambar 4 menunjukkan bahwa kelompok 1 menyelesaikan nomor 1a dengan memisalkan panjang $=\mathrm{p}$, lebar $=1$, dan tinggi $=\mathrm{t}$, sesuai gambar yang ada di soal. Selanjutnya, kelompok 1 menghasilkan rumus yang sesuai dengan kotak makanan, seperti tampak pada Gambar 4 dan tidak menggambarkannya secara geometris. Namun, kelompok 1 belum selesai mengerjakan permasalahan pada Soal bagian b, sebagaimana kelompok 2 yang telah menyelesaikan soal yang diberikan secara menyeluruh, seperti tampak pada Gambar 5.

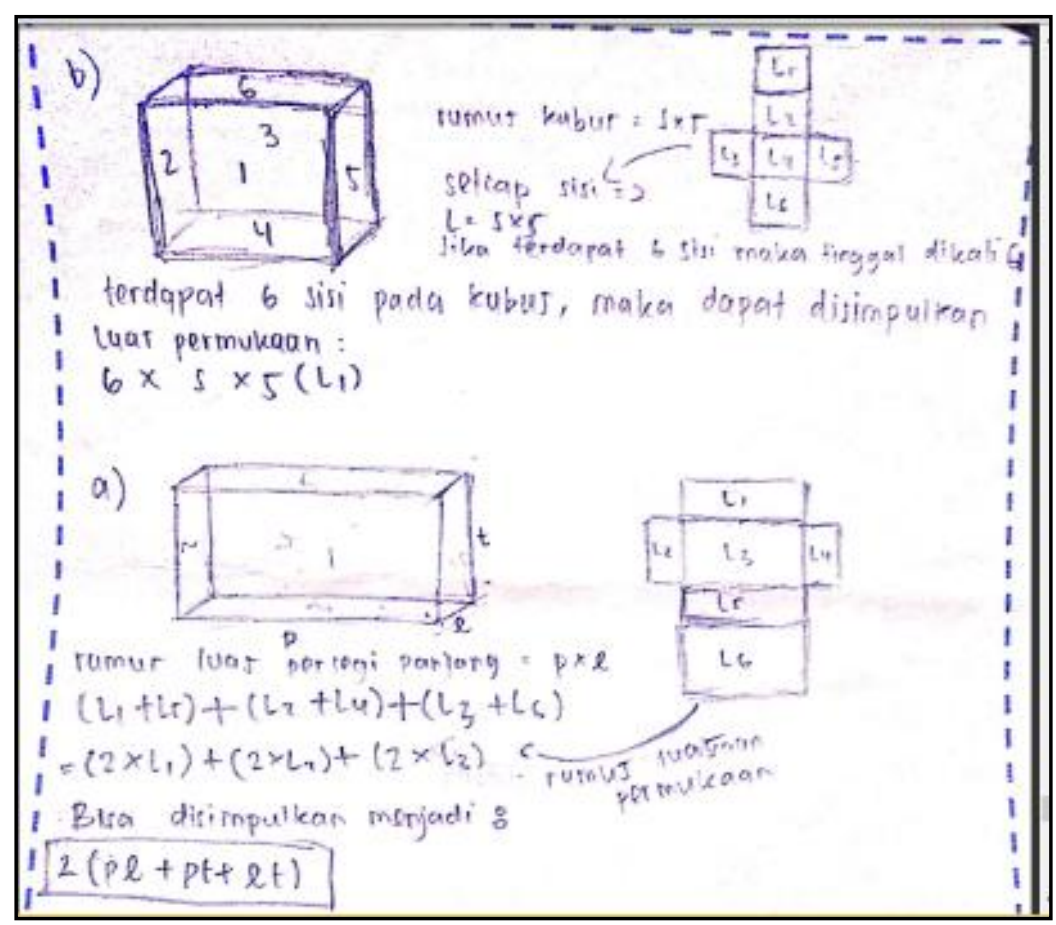

Gambar 5. Jawaban kelompok 2 untuk Masalah 1.1 
Seperti yang terlihat pada Gambar 5, kelompok 2 memulai pengerjaan dengan menggambarkan terlebih dahulu kotak makanan secara geometris dan memisalkan dengan angka untuk setiap sisinya. Kemudian, kelompok 2 menggambarkan kotak makanan, yang mana jika dibentangkan akan seperti yang terlihat disampingnya sesuai dengan sisi- sisi yang dimisalkan seperti L1, L2, L3, L4, L5, dan L6. Sehingga, dari gambar tersebut dapat dijabarkan rumusnya menjadi $2(\mathrm{pl}+\mathrm{pt}+\mathrm{lt})$. Selanjutnya, kelompok 2 menyelesaikan permasalahan nomor $b$, sama dengan langkah nomor a, seperti tampak pada Gambar 6 .

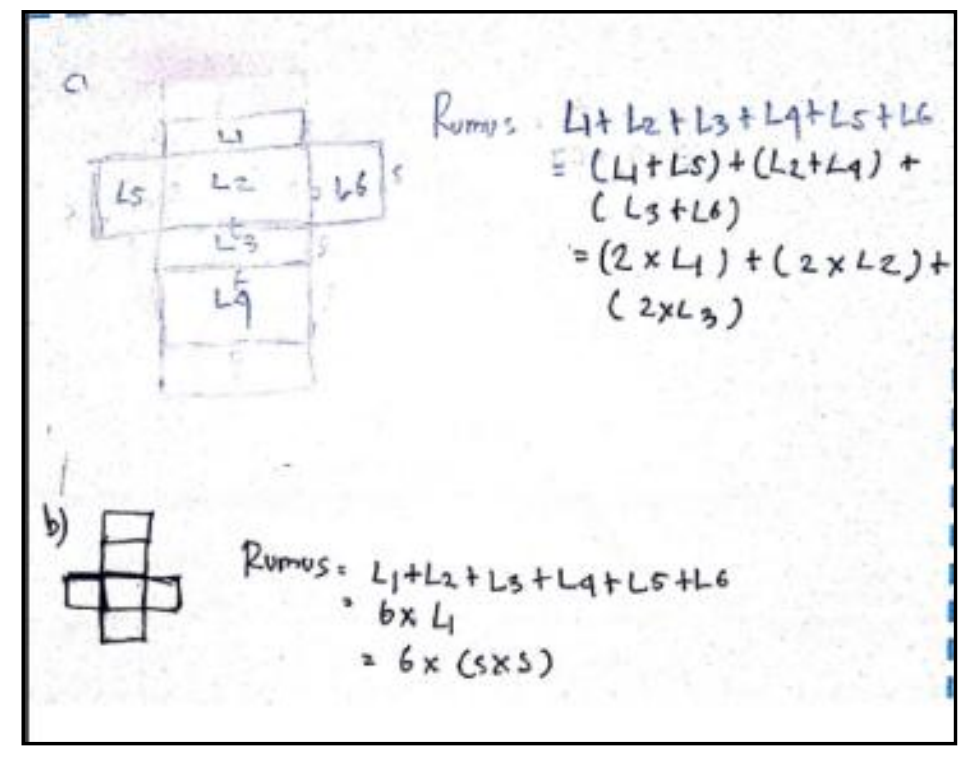

Gambar 6. Jawaban kelompok 3 untuk Masalah 1.1

Kelompok 3 menjabarkan jawaban dengan menggambarkan dan memisalkan sisisisinya dengan L1, L2, L3, L4, L5, dan L6, serta sesuai dengan permisalan yang dituliskan seperti yang terlihat pada Gambar 6. Namun, kelompok 3 tidak menjabarkan lagi luas dari sisi-sisi tersebut. Berbeda dengan nomor b, kelompok 3, tidak memisalkan sisi-sisinya, namun penjabaran rumusnya yang sesuai.

Pada Gambar 7, kelompok 4 menyelesaikan jawaban dengan menggambarkan permukaan kotak makanan dengan dibentangkan. Namun, dalam ilustrasi permisalan berbeda dengan hasil akhir rumus yang dituliskan. Hal ini, bisa dikarenakan kelompok 4 sudah mengetahui rumus nya terlebih dahulu, sehingga, apapun model gambar nya, rumus nya sama. 


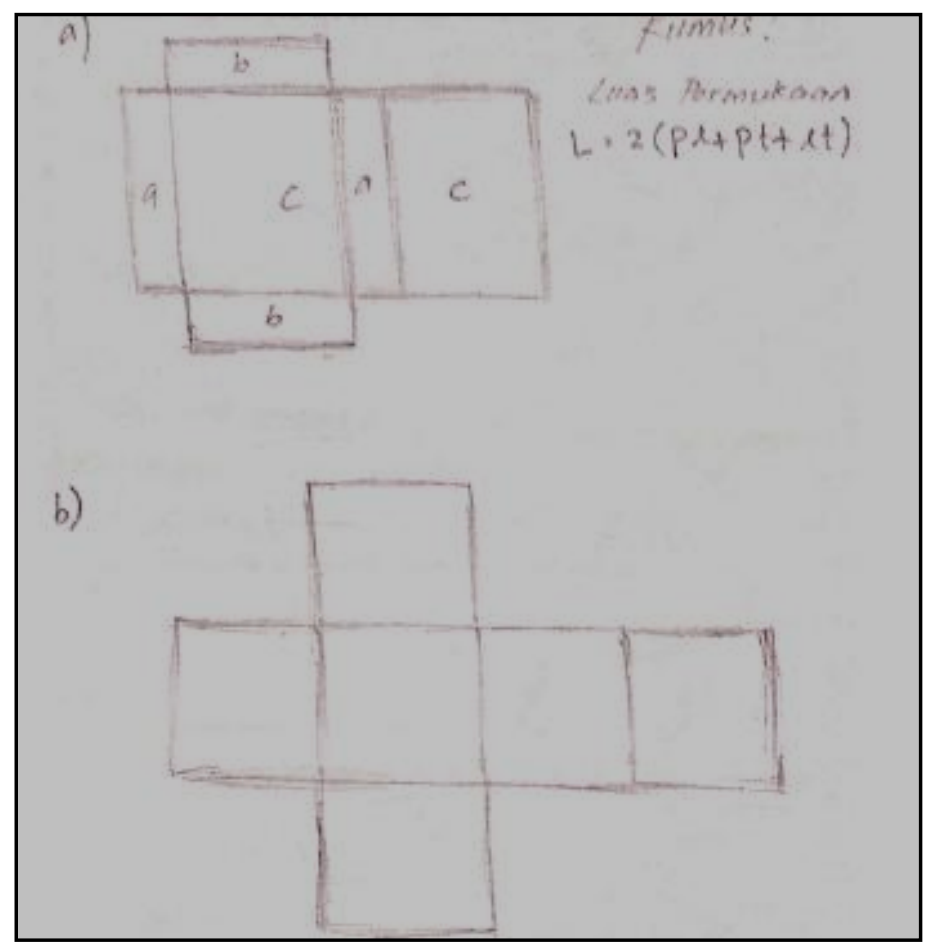

Gambar 7. Jawaban kelompok 4 untuk Masalah 1.1

2. Menghitung luas permukaan ruang kelas yang akan dicat

Tujuan dari aktivitas ini adalah siswa dapat menentukan luas permukaan ruang kelas yang di cat. Siswa dapat menyelesaikan permasalahan kontekstual dengan sejumlah jawaban dan model pengerjaan yang diselesaikan secara matematis dan kemudian hasilnya dikembalikan kembali ke bentuk kontekstual, sehingga bisa menyelesaikan permasalahan kontekstual yang diberikan. Adapun soal kontekstual yang diberikan, seperti tampak pada Gambar 8.

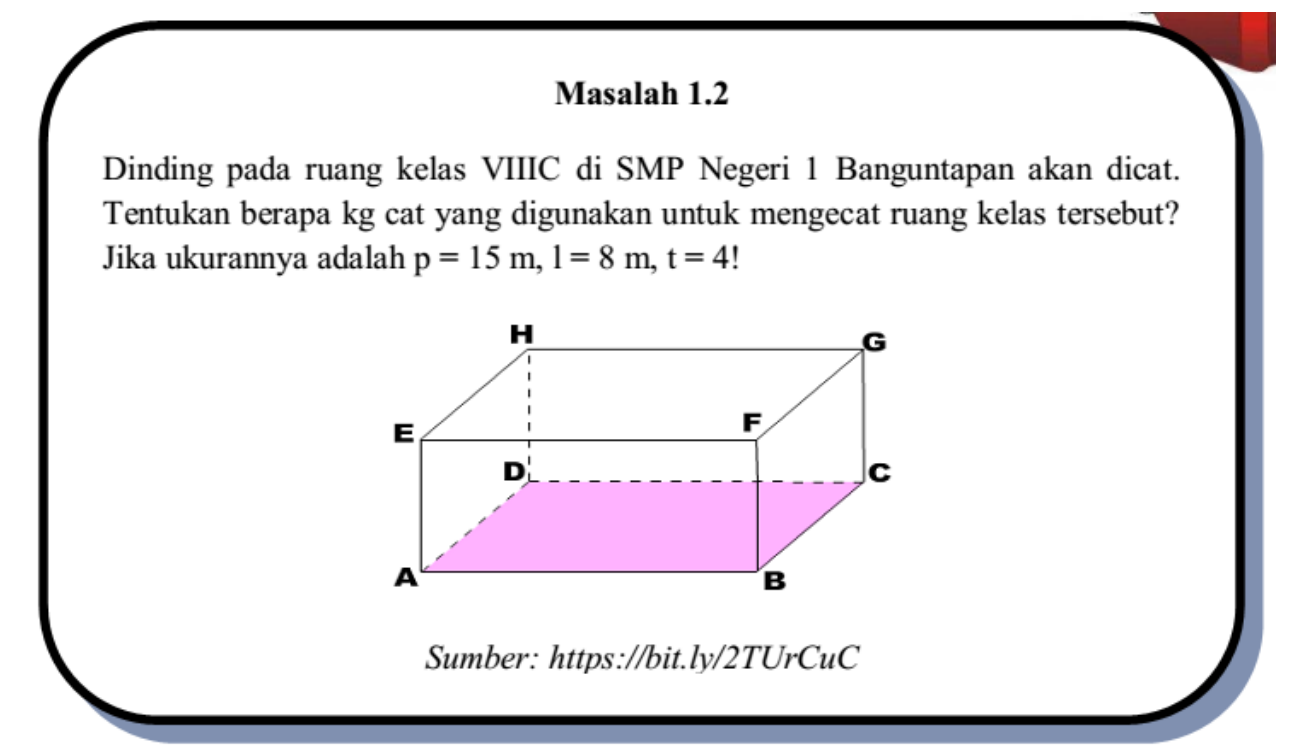

Gambar 8. LAS 1 untuk Masalah 1.2 
Selanjutnya, Gambar 9 menunjukkan bahwa sejumlah siswa mengalami kesulitan dalam menyelesaikan Masalah 1.2. Kesulitan siswa terhadap Masalah 1.2, terkait permasalahan, apakah lantai dan atap dicat juga atau tidak, seperti tampak pada Dialog 4 .

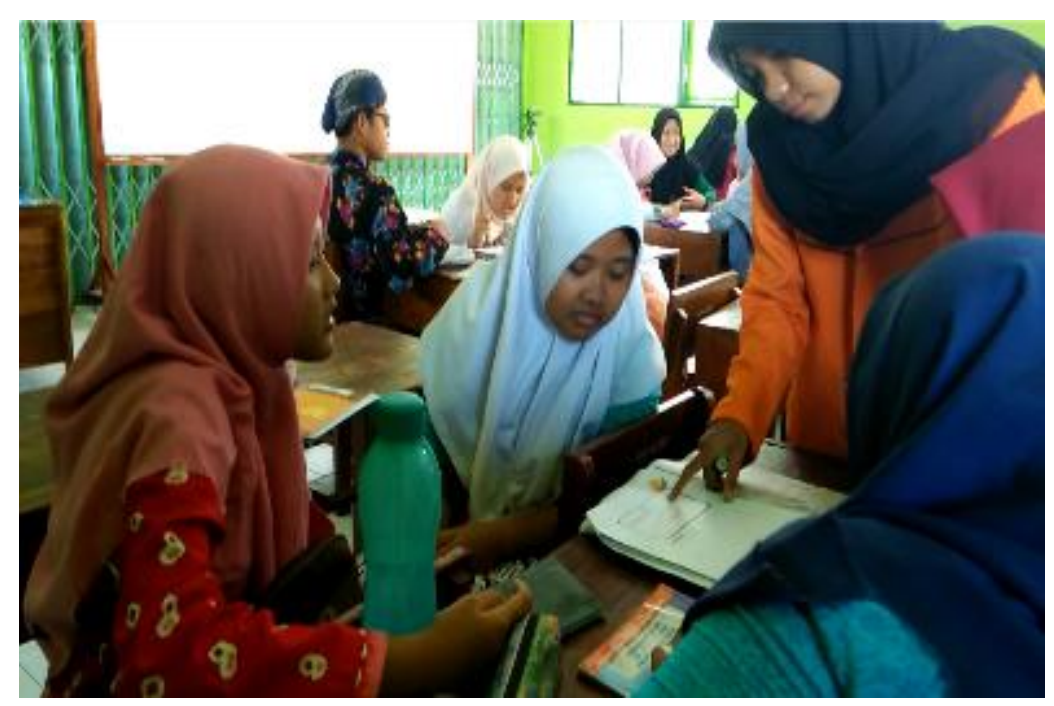

Gambar 9. Siswa tampak kesulitan dalam menyelesaikan Masalah 1.2

\section{Dialog 4}

Siswa : Mba, apakah ruangan yang dicat hanya dindingnya saja atau semuanya?

Guru : Di dalam kehidupan nyata menurut kalian bagaimana?

Siswa : Hanya dindingnya saja hehe

Guru : Ya seperti itu

Kelompok 1 menghitung luas permukaan dimulai dari menggunakan rumus luas permukaan balok terlebih dahulu, setelah itu memasukkan nilai-nilainya, sehingga didapatkan hasilnya adalah $424 \mathrm{~m}^{2}$, seperti tampak pada Gambar 10 .

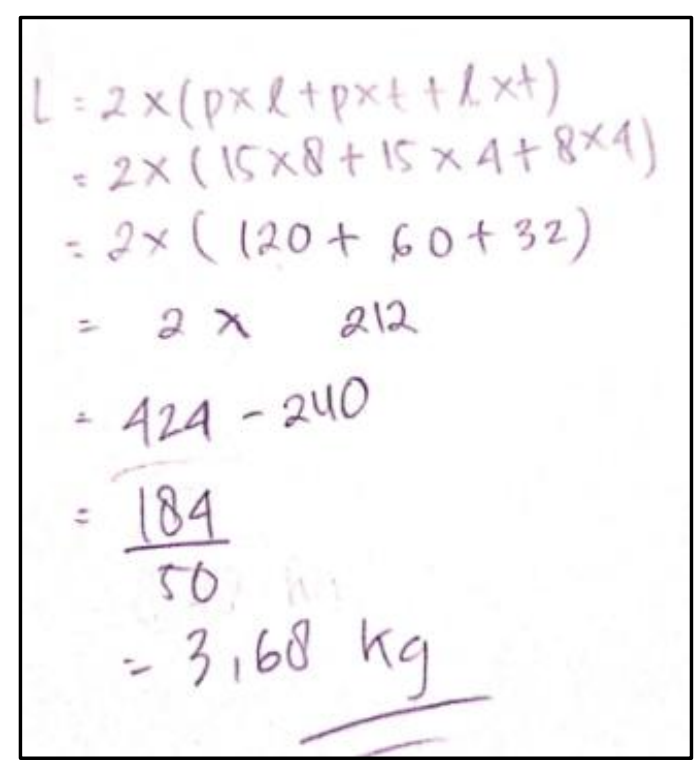

Gambar 10. Jawaban kelompok 1 untuk Masalah 1.2 
Karena atap dan lantai tidak dicat, maka hasil perhitungannya dikurangi 2 × p x $1=240$, maka hasilnya adalah $184 \mathrm{~m} 2$. Setelah itu, karena perintah soalnya setiap $50 \mathrm{~m}^{2}$ dinding, diperlukan $1 \mathrm{~kg}$ cat maka 184 dibagi dengan 50 menghasilkan 3,68 kg cat. Jadi, cat yang diperlukan untuk mengecat ruang kelas tersebut adalah 3,68 kg.

Selanjutnya, kelompok 2, 3, 4, dan 5 juga menggunakan langkah yang sama seperti yang dilakukan oleh kelompok 1, yaitu menggunakan pengetahuan kontekstualnya, yaitu lantai dan atap tidak dicat dikarenakan hanya dinding kelas saja yang dicat, seperti tampak pada Gambar 11.
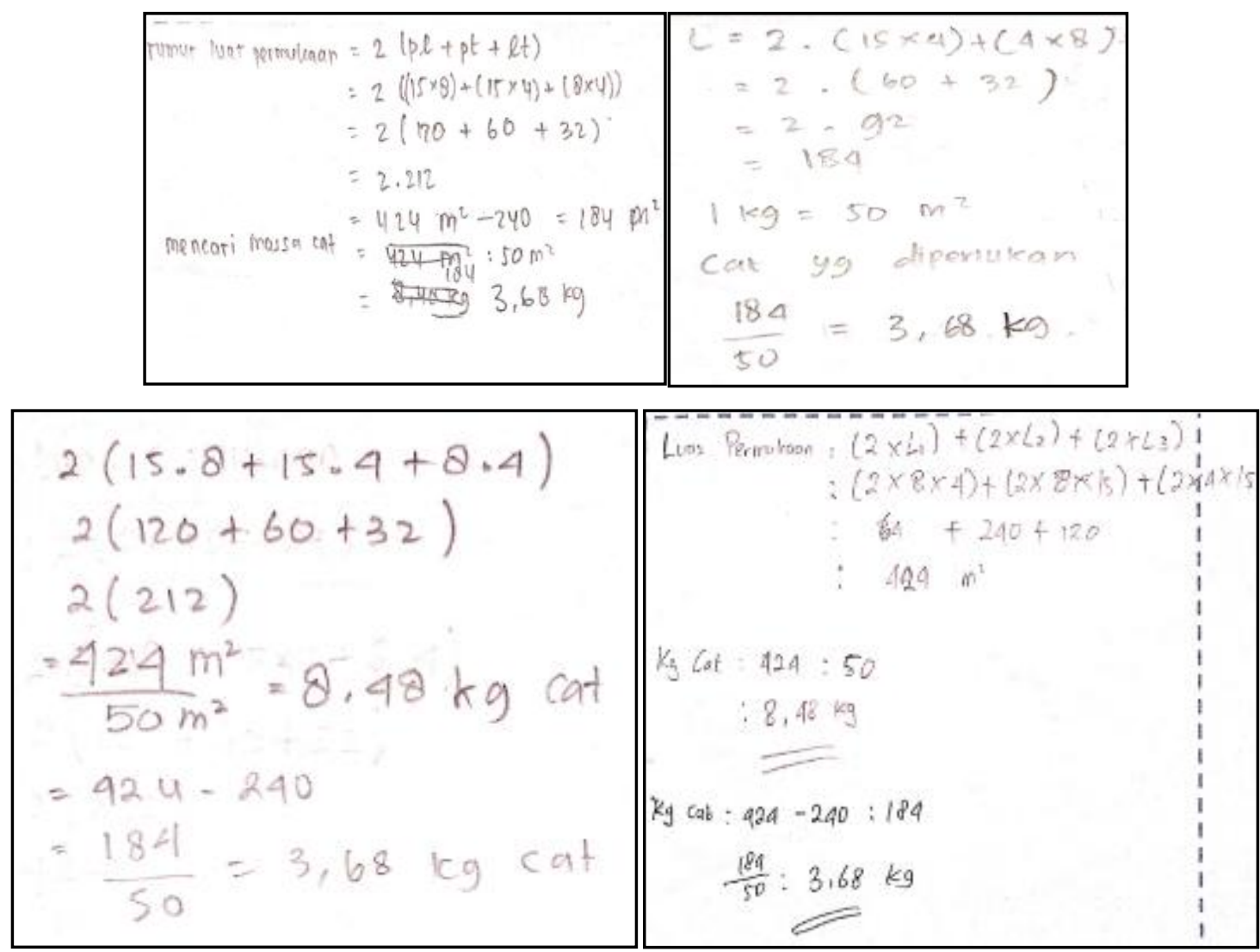

Gambar 11. Jawaban kelompok 2, 3, 4 dan 5 untuk Masalah 1.2

Kelompok 6 dan 7 menggunakan langkah awal yang sama dengan kelompok sebelumnya, yaitu menggunakan rumus luas permukaan balok terlebih dahulu. Setelah itu, memasukkan nilai-nilai nya. Kemudian, langsung dibagi dengan 50 tanpa mengurangi luas dari lantai dan atapnya, seperti tampak pada Gambar 12. Hal ini menunjukkan kelompok ini masih ditahapan perhitungan matematis, tanpa membawa hasil nya ke permasalahan kontekstual. 


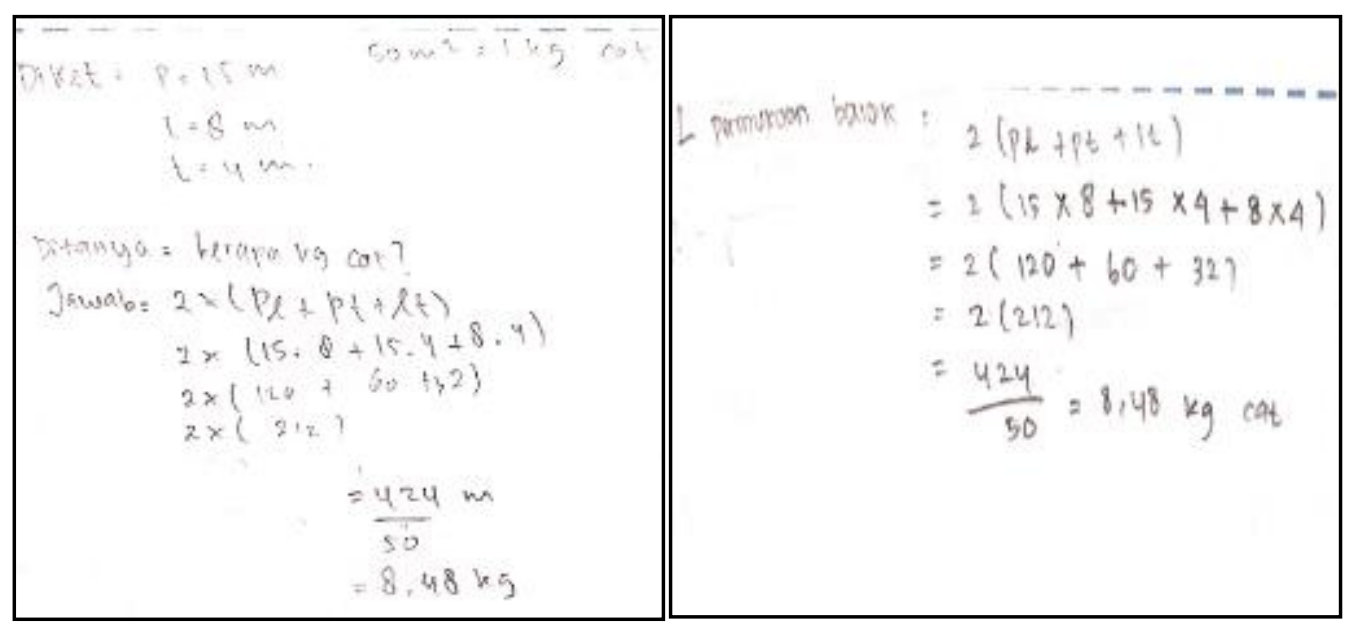

Gambar 12. Jawaban kelompok 6 dan 7 untuk Masalah 1.2

3. Menghitung biaya yang diperlukan untuk membungkus kado

Tujuan dari aktivitas ini adalah agar siswa dapat memahami dan menyelesaikan dalam kehidupan nyata dengan menggunakan cara mereka masing-masing. Untuk mencapai tujuan tersebut, peneliti memberikan permasalahan, Masalah 1.3, seperti tampak pada Gambar 13 . Permasalahan ini digunakan untuk mengeksplorasi pengetahuan siswa dalam menyelesaikan permasalahan menghitung luas permukaan bangun ruang sisi datar, yang dapat diimplementasikan dalam menyelesaikan permasalahan sehari-hari.

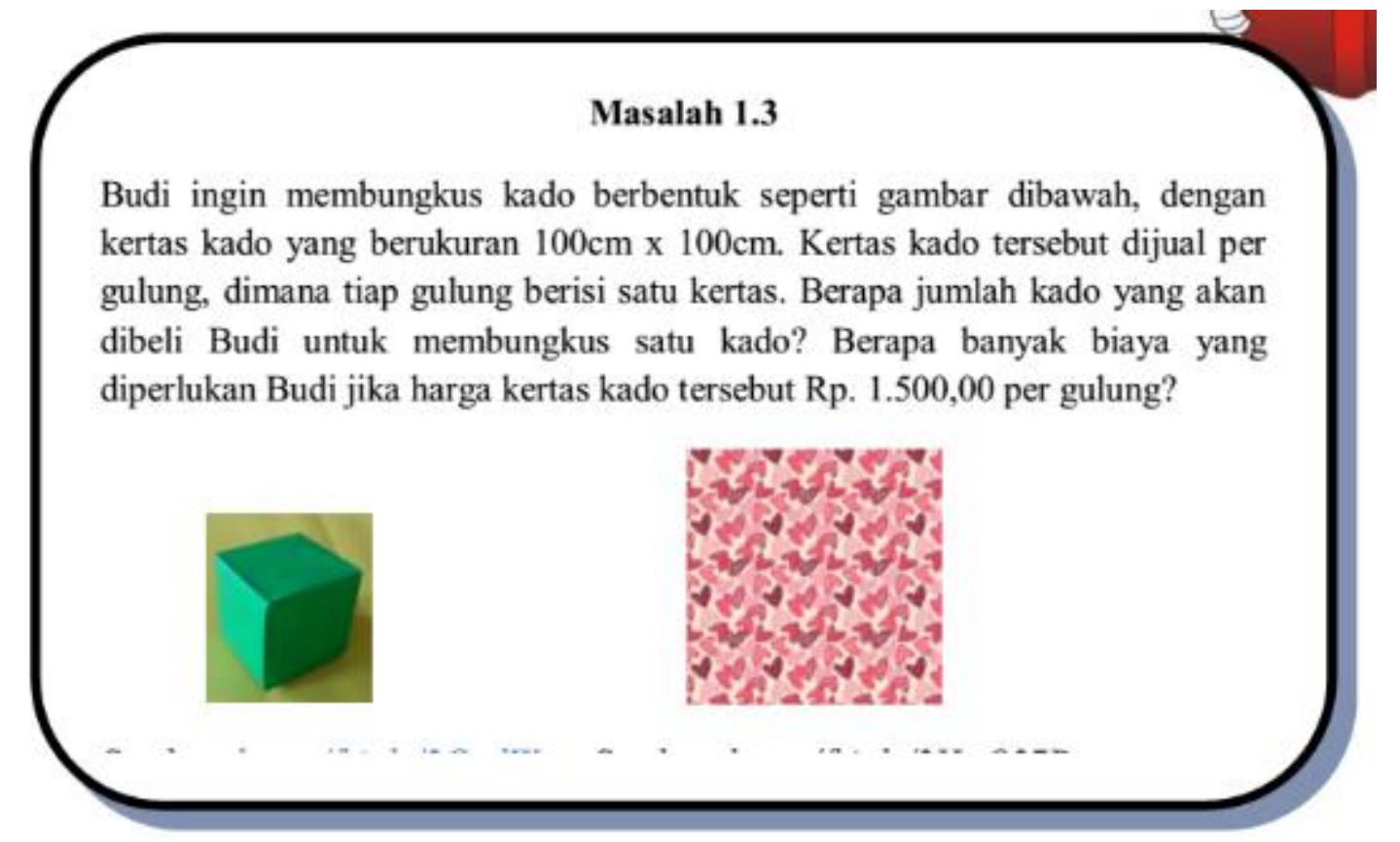

Gambar 13. LAS 1 untuk Masalah 1.3 
Pada Gambar 14, terlihat siswa sedang melakukan proses mengkonstruksi pengetahuan bersama dengan guru untuk menyelesaikan Masalah 1.3. Guru bertindak sebagai fasilitator selama proses pembelajaran untuk memfasilitasi proses konstruksi pengetahuan siswa.

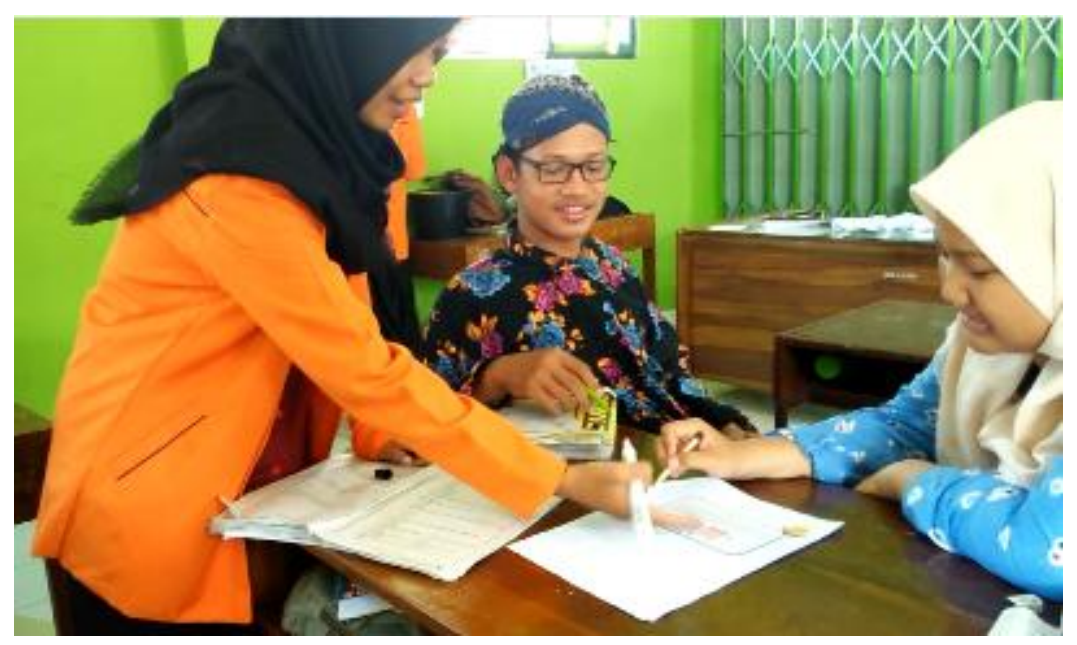

Gambar 14. Siswa Melakukan Proses Konstruksi Dengan Guru

Selanjutnya, Dialog 5 menunjukkan bahwa kegiatan siswa mengkonstruksi solusi dari Masalah 1.3. Hal tersebut juga merupakan salah satu karakteristik dari PMRI yaitu interaktivitas.

\section{Dialog 5}

Siswa : Mba, berarti langkah awalnya itu kita cari luas kertas kado dan kadonya ya?

Guru : Iya tepat sekali, trus bagaimana lagi?

Siswa : Setelah diperoleh kedua luas permukaan tersebut, kita bagi didapatlah hasilnya lalu dikalikan dengan Rp.1.500

Guru : Iya kira-kira seperti itu

Untuk proses penyelesaian masalah yang diberikan, kelompok 1 menggunakan rumus dari luas permukaan kubus serta mengamati terlebih dahulu soal dan gambar pada soal, seperti terlihat pada Gambar 15. Kemudian memasukkan nilai panjang sisi kubus ke dalam rumus luas permukaan kubus. Kelompok 1 tidak memberikan keterangan pada setiap langkah yang dikerjakan. Sehingga, hasil akhirnya adalah 27000. Kesalahan yang dilakukan oleh mereka, terletak pada kurang keterangan pada setiap langkahnya dan juga hasil akhir kurang tepat. 


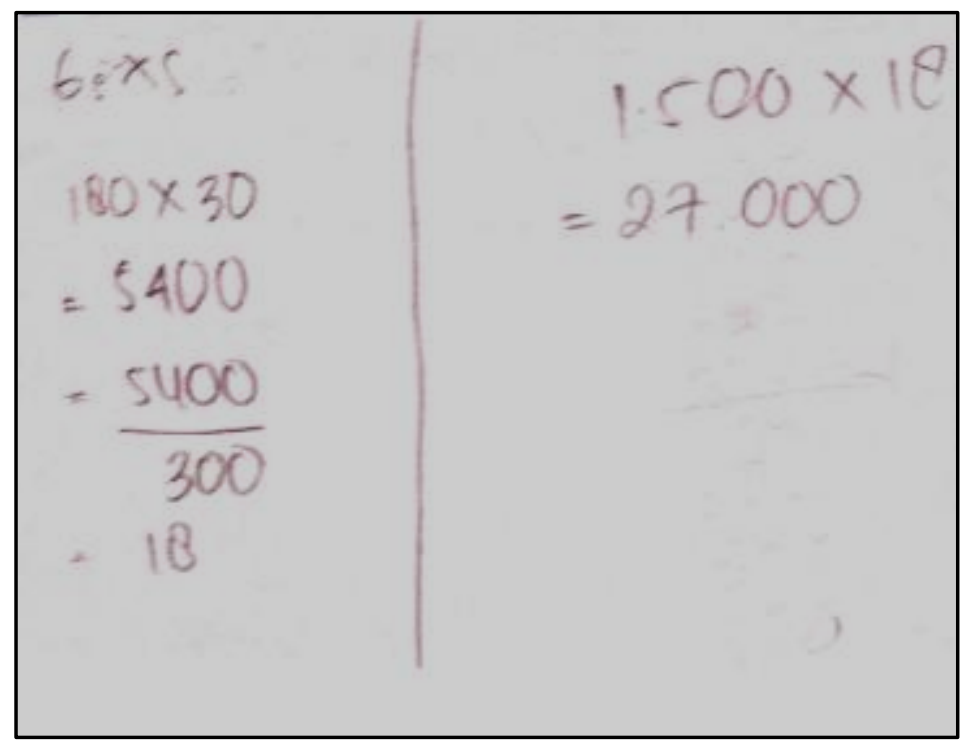

Gambar 15. Jawaban kelompok 1 untuk Masalah 1.3

Kelompok 2 menggunakan luas permukaan kubus terlebih dahulu, sehingga nilainya adalah $5400 \mathrm{~cm}^{2}$. Kemudian menggunakan rumus luas dari persegi panjang yaitu $\mathrm{p}$ x 1 yang nilainya adalah $3000 \mathrm{~cm}^{2}$. Setelah itu, untuk mendapatkan jumlah kertas kado yang akan digunakan, maka luas permukaan kado dibagi dengan luas kertas kado yang berbentuk persegi panjang, sehingga hasilnya adalah 1,8 gulung kertas kado. Kemudian, siswa mengalikan 1,8 gulung kertas kado dengan harga kertas kado 1500 per gulung adalah 2700. Sehingga harga yang harus dibayar adalah Rp. 2.700. Untuk lebih jelasnya, dapat dilihat pada Gambar 16.

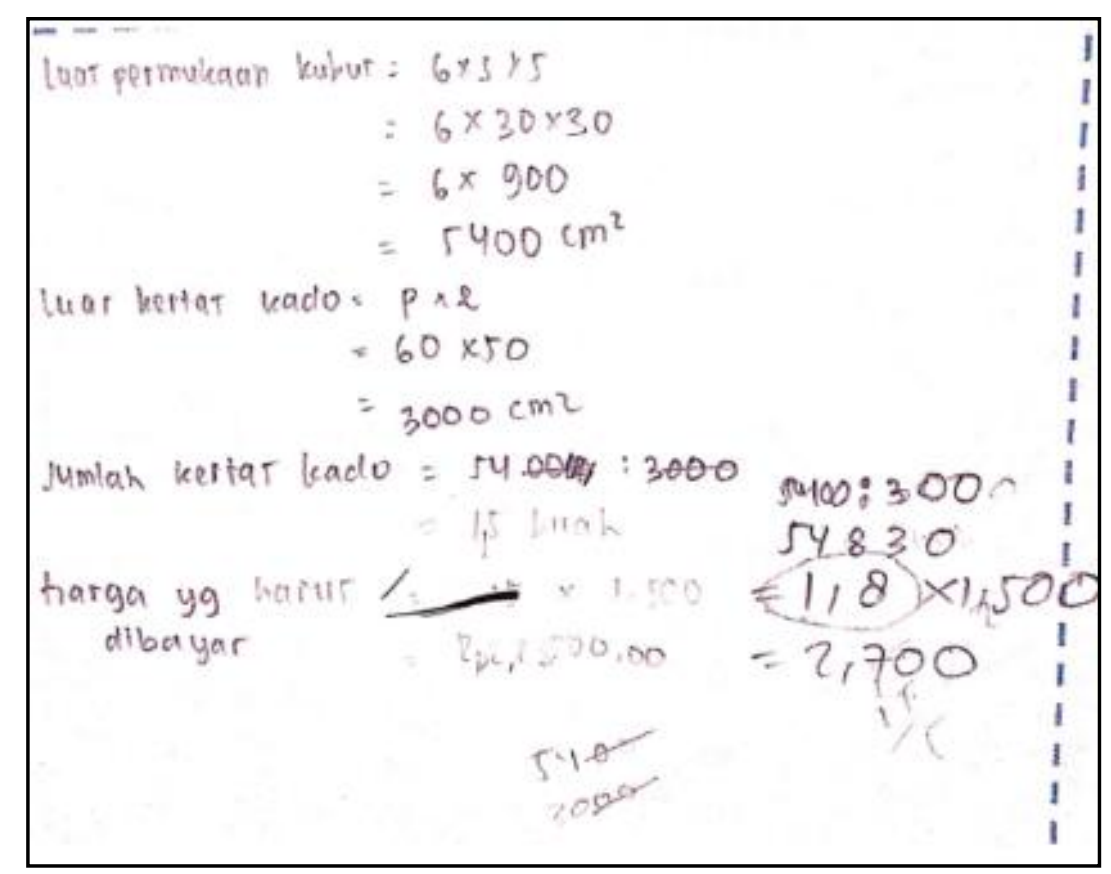

Gambar 16. Jawaban kelompok 2 untuk Masalah 1.3 
Kelompok 3 hampir sama dengan kelompok 2. Perbedaannya terletak pada kesalahan membagi pada jumlah kertas kado yang dipakai, seperti tampak pada Gambar 17. Mereka menulis 5400 dibagi dengan 3000 menghasilkan 1,5 buah, padahal jika dibagi hasilnya adalah 1,8 buah. Sehingga, harga yang harus dibayar tidak tepat yaitu Rp. 2.250.

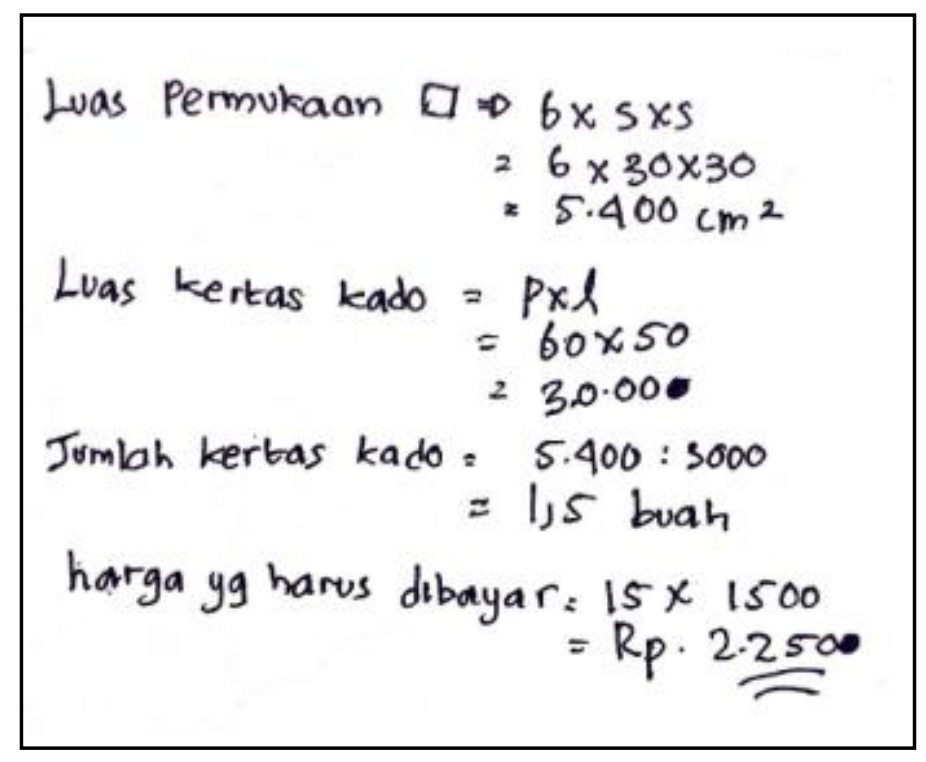

Gambar 17. Jawaban kelompok 3 untuk Masalah 1.3

Kelompok 4 juga sama dengan kelompok 1, yaitu tidak memberikan keterangan yang lebih detail, seperti tampak pada Gambar 18. Namun, langkah-langkahnya sudah benar dan hasilnya pun sudah benar yaitu Rp. 2.700 .

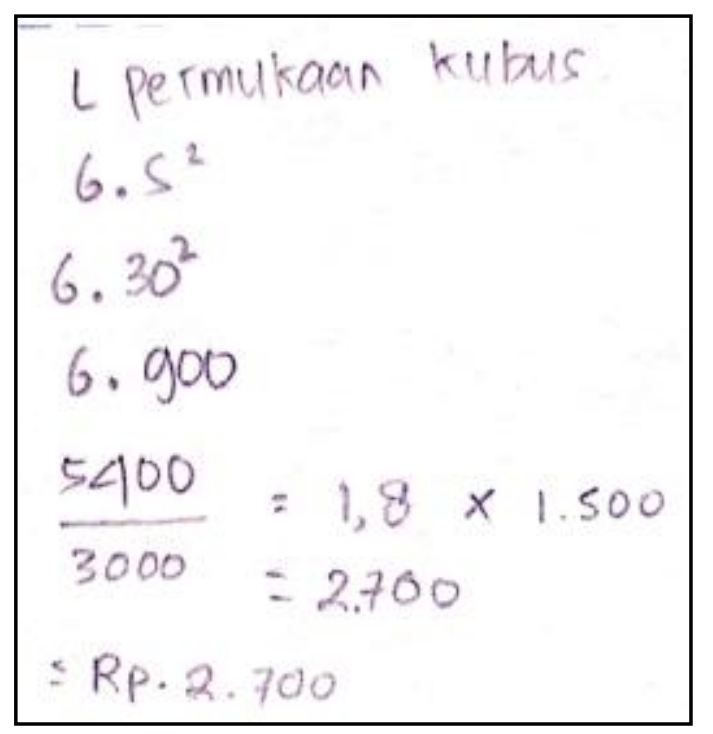

Gambar 18. Jawaban kelompok 4 untuk Masalah 1.3

Terakhir, kelompok 5 menggunakan rumus yang sama dengan kelompok 2 dan 3 . Kemudian, luas permukaan kado dibagi dengan luas kertas kado adalah 1,8 cm. Satuan yang 
digunakan kurang tepat, seperti tampak pada Gambar 19. Hasil yang sebenarnya adalah 1,8 gulung atau buah. Hasil akhirnya adalah Rp. 2.700.

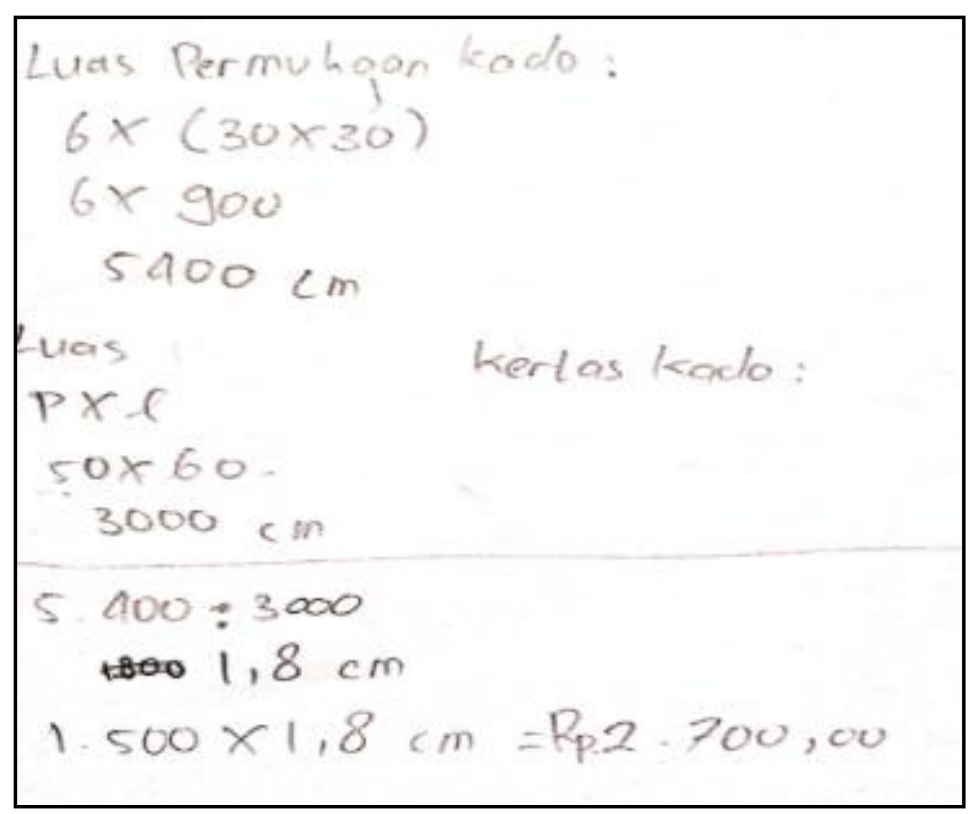

Gambar 19. Jawaban kelompok 5 untuk Masalah 1.3

\section{Pertemuan Kedua}

Pertemuan kedua masih berkaitan dengan luas permukaan bangun ruang sisi datar. Namun, kasus yang diberikan menggunakan bangun ruang yang berbeda yaitu prisma dan limas. Terdapat tiga aktivitas dalam pertemuan ini. Selanjutnya, ketiga aktivitas tersebut terdiri dari aktivitas menemukan rumus luas permukaan prisma dan limas, menghitung luas kain yang diperlukan untuk membuat tenda, dan menghitung harga plakat akrilik.

Sebelum membagikan LAS 2 ke tiap kelompok, siswa diberi model yang dapat dibayangkan oleh siswa untuk menyelesaikan masalah-masalah di LAS 2 seperti yang terlihat pada Gambar 20. 


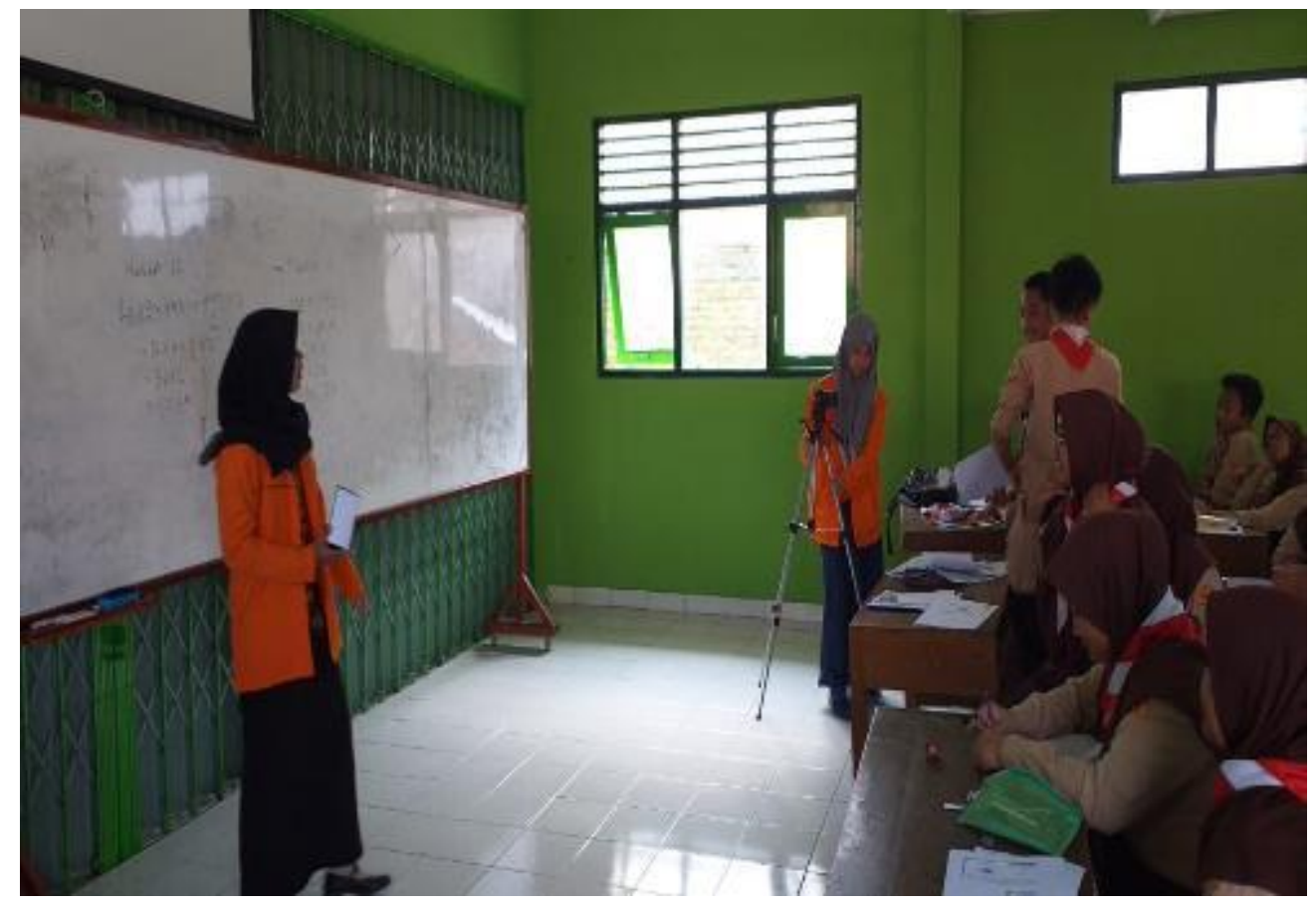

Gambar 20. Guru mendemonstrasikan model bangun ruang prisma dan limas

Gambar 21 menunjukkan bahwa siswa begitu antusias untuk mengerjakan LAS 2 yang dibagikan. Setelah itu guru mengelilingi tiap kelompok dengan mendemonstrasikan ke tiap kelompok supaya siswa dapat mengkontruksi pemikirannya kembali terhadap apa yang telah didapatkan sebelumnya. Pada pertemuan ini, siswa sudah bisa menerapkan strategi atau model penyelesaian atas permasalahan yang diberikan, seperti pada pertemuan pertama melalui LAS 2 yang dibagikan. Siswa juga selama proses pembelajaran berlangsung telah memenuhi prinsip dan karakteristik dari Pendekatan PMRI, yaitu guided reinvention(menemukan kembali) melalui progressive Mathematizing (matematisasi progresif), dan Didactical Phenomenology (fenomena didaktik), dan Self Developed Models (pengembangan model sendiri). Selanjutnya, kelima karakteristik PMRI yang tampak selama proses pembelajaran, yaitu menggunakan masalah kontekstual, berbagai model yang dibangun siswa, kontribusi siswa, interactivity (interaktivitas), dan Intertwining (keterkaitan). 


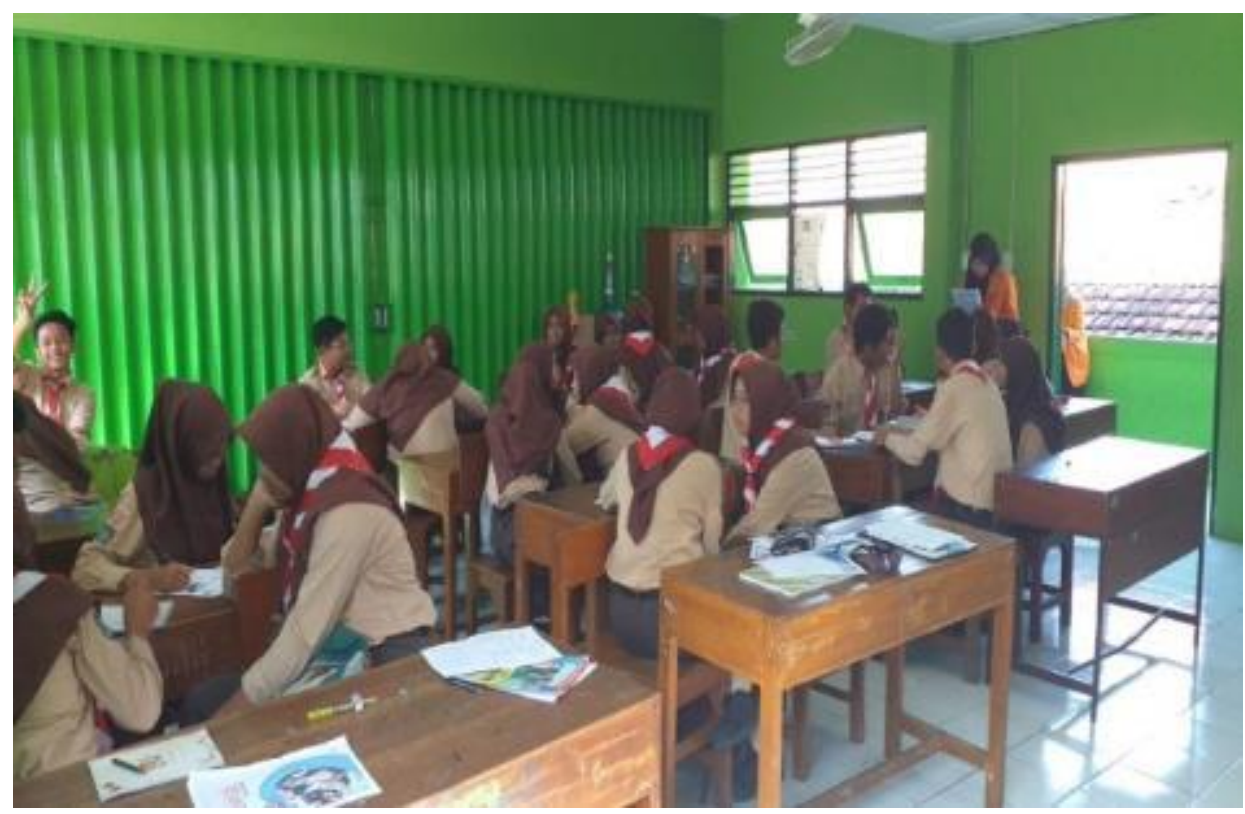

Gambar 21. Siswa duduk per kelompok dan guru membagikan LAS 2

\section{Pertemuan Ketiga}

Pada pertemuan terakhir ini, peneliti memberikan evaluasi akhir pembelajaran dalam bentuk tes. Tes tersebut digunakan untuk mengetahui hasil belajar siswa dalam ranah kognitif tipe C3 (menerapkan). Gambar 22 menunjukkan hasil data tes siswa dari 3 soal yang diberikan.

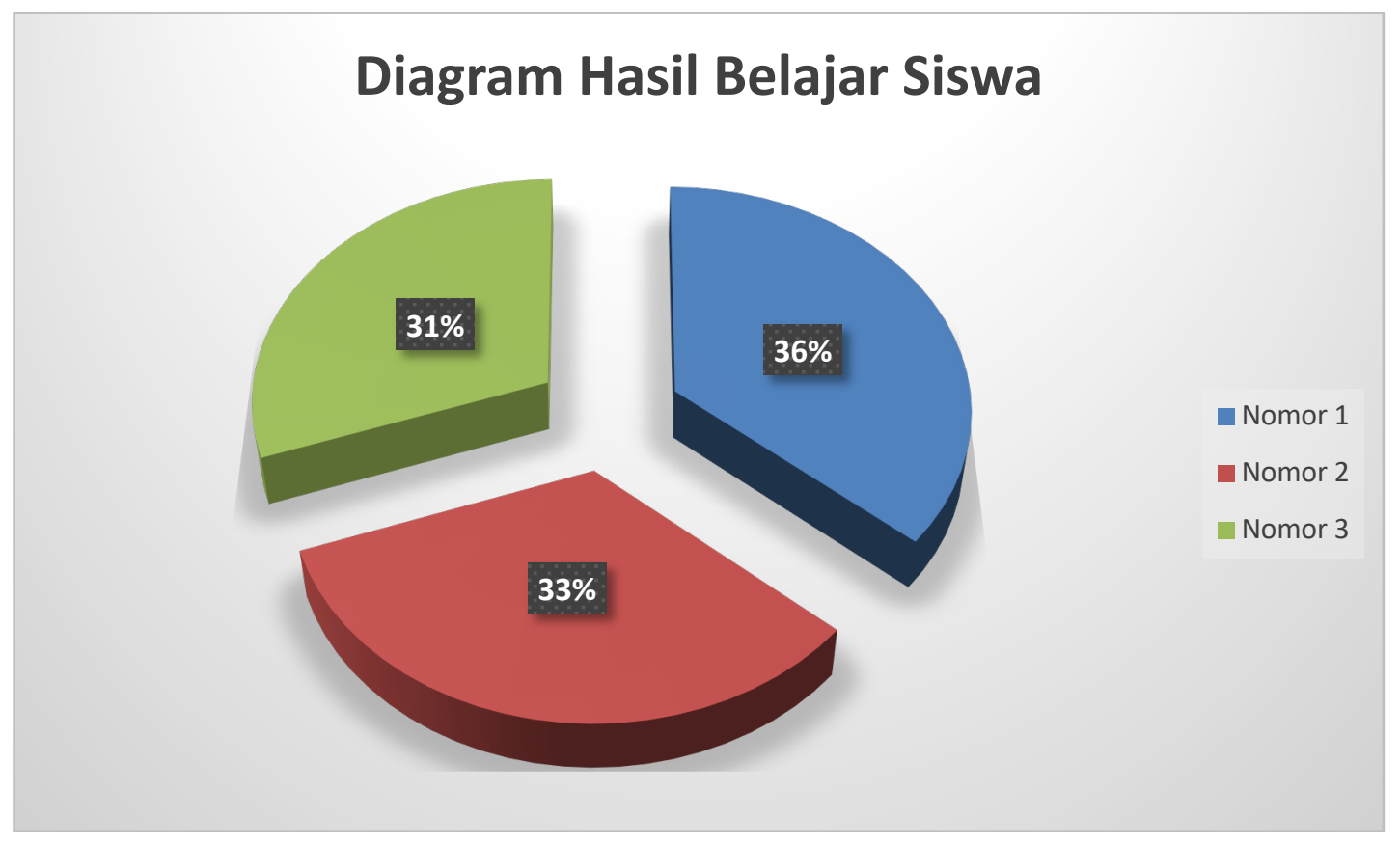

Gambar 22. Hasil belajar siswa setelah diberikan pembelajaran PMRI 
Sebanyak 25 orang dapat menjawab soal nomor 1 dengan benar. Pada soal nomor 2, sebanyak 23 orang menjawab dengan benar. Untuk soal nomor 3, sebanyak 21 orang menjawab dengan benar. Ada beberapa kesalahan yang dilakukan siswa dalam menyelesaikan soal-soal tersebut yaitu siswa kurang teliti dalam memahami soal serta siswa kurang teliti dalam perhitungan.

\section{Simpulan}

Hasil penelitian menunjukkan bahwa dalam pembelajaran luas permukaan bangun ruang sisi datar melalui Lembar Aktivitas Siswa (LAS) berbasis pendekatan pembelajaran Pendidikan Matematika Realistik Indonesia (PMRI), LAS tersebut memuat soal-soal yang dapat menemukan konsep untuk menemukan rumus dari luas permukaan bangun ruang sisi datar. Selain itu, siswa dapat menggunakan kemampuan untuk mengkontruksi pengetahuan sebelumnya untuk menyelesaikan masalah yang ada di LAS. Oleh sebab ini, peran pendekatan PMRI dapat membantu siswa dalam memahami konsep luas permukaan bangun ruang sisi datar melalui pembelajaran dunia nyata atau konteks yang dialami siswa menggunakan LAS yang diberikan. Pembelajaran yang berlangsung selama 2 pertemuan menggunakan pendekatan PMRI mendeskripsikan bahwa pembelajaran ini telah memenuhi 5 aspek dari karakteristik PMRI yang merupakan ciri khas dari pembelajaran PMRI.

\section{Referensi}

Ahamad, S. N. S. H., Li, H. C., Shahrill, M., \& Prahmana, R. C. I. (2018). Implementation of problem-based learning in geometry lessons. Journal of Physics: Conference Series, 943(1), 012008. https://doi.org/10.1088/1742-6596/943/1/012008.

Angraini, P., \& Prahmana, R. C. I. (2019). Misconceptions of seventh grade students in solving geometry problem type national examinations. Journal of Physics: Conference Series, 1188(1), 012101. https://doi.org/10.1088/1742-6596/1188/1/012101.

Asis, M., \& Arsyad, A. N. (2015). Profil kemampuan spasial dalam menyelesaikan masalah geometri siswa yang memiliki kecerdasan logis matematis tinggi ditinjau dari perbedaan gender. Daya Matematis: Jurnal Inovasi Pendidikan Matematika, 3(1), 78-87. https://doi.org/10.26858/jds.v3i1.1320.

Diba, F., Zulkardi, \& Saleh, T. (2009). Pengembangan materi pembelajaran bilangan berdasarkan Pendidikan Matematika Realistik untuk siswa kelas V Sekolah Dasar. Jurnal Pendidikan Matematika, 3(1), 33-46. https://doi.org/10.22342/jpm.3.1.319.

Fiantika, F. R., Budayasa, I. K., \& Lukito, A. (2017). Membangun definisi genetis kubus melalui distorsi dan manipulasi objek spasial. Jurnal Elemen, 3(2), 130-137. https://doi.org/10.29408/jel.v3i2.403.

Gravemeijer, K. P. E. (1994). Developing realistic mathematics education: ontwikkelen van realistisch reken/wiskundeonderwijs. Utrecht: CD-[beta] Press.

Hadi, S. (2017). Pendidikan matematika realistik. Depok: RajaGrafindo Persada. 
Jannah, A. F., \& Prahmana, R. C. I. (2019). Learning fraction using the context of pipettes for seventh-grade deaf-mute student. Journal for the Education of Gifted Young Scientists, 7(2), 299-321. https://doi.org/10.17478/jegys.576234.

Meryansumayeka, \& Suganda, V. A. (2018). Pengembangan video pembelajaran berbasis PMRI untuk mendukung mental calculation siswa dalam permasalahan aritmatika sosial. Jurnal Elemen, 4(2), 119-130. https://doi.org/10.29408/jel.v4i2.634.

Misdalina, Zulkardi, \& Purwoko. (2013). Pengembangan materi integral untuk Sekolah Menengah Atas (SMA) menggunakan pendekatan Pendidikan Matematika Realistik Indonesia (PMRI) di Palembang. Jurnal Pendidikan Matematika, 3(1), 61-74. https://doi.org/10.22342/jpm.3.1.321.

Novita, R., Prahmana, R. C. I., Fajri, N., \& Putra, M. (2018). Penyebab kesulitan belajar geometri dimensi tiga.Jurnal Riset Pendidikan Matematika,5(1), 18-29. https://doi.org/10.21831/jrpm.v5i1.16836.

Nurhikmayati, I. (2017). Kesulitan berpikir abstrak matematika siswa dalam pembelajaran problem posing berkelompok. Kalamatika: Jurnal Pendidikan Matematika, 2(2), 159176. https://doi.org/10.22236/KALAMATIKA.vol2no2.2017pp159-176.

Prabowo, A., \& Ristiani, E. (2011). Rancang bangun instrumen tes kemampuan keruangan pengembangan tes kemampuan keruangan Hubert Maier dan identifikasi penskoran berdasar teori Van Hielle. Kreano, Jurnal Matematika Kreatif-Inovatif, 2(2), 72-87.

Prahmana, R. C. I. (2017). Design research (teori dan implementasinya: suatu pengantar). Depok: Rajawali Press.

Prahmana, R. C. I., Zulkardi, \& Hartono, Y. (2012). Learning multiplication using indonesian traditional game in third grade. Journal on Mathematics Education, 3(2), 115-132. https://doi.org/10.22342/jme.3.2.1931.115-132.

Putri, R. I. I. (2016). Pengaruh interaksi pendekatan pembelajaran dan bentuk tes formatif terhadap hasil belajar matematika. Jurnal Pendidikan dan Pembelajaran (JPP), 22(1), 69-75. https://doi.org/10.21831/cp.v1i1.8366.

Romadiastri, Y. (2013). Penerapan pembelajaran kontekstual pada Kalkulus 2 bahasan volume benda putar. Jurnal Phenomenon, 3(1), 131-143. https://doi.org/10.21580/phen.2013.3.1.179.

Saefudin, A. A. (2012). Pengembangan kemampuan berpikir kreatif siswa dalam pembelajaran matematika dengan pendekatan Pendidikan Matematika Realistik Indonesia (PMRI). Jurnal Al Bidayah, 4(1), 37-48.

Saputra, N. N., \& Andriyani, R. (2019). Pengembangan perangkat pembelajaran matematika interaktif kelas VIII SMP berbasis konstruktivis. Prima: Jurnal Pendidikan Matematika, 6(1), 1-12.

Sembiring, R. K., Hoogland, K., \& Dolk, M. (Eds.) (2010). A Decade of PMRI in Indonesia. Utrecht: APS International

Umam, K., \& Supiat. (2019). Pengaruh pembelajaran kooperatif tipe STAD dengan bantuan website terhadap kemampuan pemahaman konsep geometri siswa kelas VIII. Jurnal Elemen, 5(2), 170-177. https://doi.org/10.29408/jel.v5i2.1297.

Wijaya, A. (2012). Pendidikan matematika realistik: suatu alternatif pendekatan pembelajaran matematika. Yogyakarta: Graha Ilmu.

Winarso, W., \& Dewi, W. Y. (2017). Berpikir kritis siswa ditinjau dari gaya kognitif visualizer dan verbalizer dalam menyelesaikan masalah geometri. Beta: Jurnal Tadris Matematika, 10(2), 117-133. https://doi.org/10.20414/betajtm.v10i2.109. 